\title{
Development and characterization of DNA microsatellite primers for buriti (Mauritia flexuosa L.f.)
}

\author{
E.V. Menezes ${ }^{1}$, W.F.S. Souto ${ }^{1}$, A.Y. Ciampi², V.C.R. Azevedo ${ }^{2}$, \\ H.M. Valério ${ }^{1}$ and M.A.S. Pimenta ${ }^{1}$ \\ ${ }^{1}$ Laboratório de Genética da Conservação, \\ Universidade Estadual de Montes Claros, \\ Campus Universitário Professor Darcy Ribeiro, Montes Claros, MG, Brasil \\ ${ }^{2}$ Laboratório de Genética Vegetal, \\ Embrapa Recursos Genéticos e Biotecnologia, Brasília, DF, Brasil
}

Corresponding author: M.A.S. Pimenta

E-mail: marcio.pimenta@unimontes.br

Genet. Mol. Res. 11 (4): 4058-4062 (2012)

Received December 14, 2011

Accepted May 30, 2012

Published September 17, 2012

DOI http://dx.doi.org/10.4238/2012.September.17.6

\begin{abstract}
Mauritia flexuosa L. (Arecaceae) is a palm tree species known as buriti that occurs in the Cerrado biome. It is characteristic of the vereda, a typical ecosystem of central Brazil. In this phytophysiognomy, $M$. flexuosa and other groups of arboreal-herbaceous species develop in open fields with very humid soils. M. flexuosa can be found in forest borders and is a palm tree with a wide distribution in South America (Brazil, Colombia, Venezuela, French Guyana Ecuador, Peru, and Bolivia). The main objectives of this study were to develop simple sequence repeat marker-enriched libraries and to characterize these loci in buriti palm to facilitate future population studies. A total of 40 sequences derived from the microsatellite-enriched libraries were selected for primer design. The optimization results showed that 9 primer pairs could successfully amplify polymorphic target fragments of the expected sizes. The data also show that the described primers
\end{abstract}


can be used in population genetic studies in M. flexuosa to obtain information that will inform conservation and management strategies.

Key words: Mauritia flexuosa; Microsatellites; Conservation genetics

\section{INTRODUCTION}

The Brazilian Cerrado is one of the largest biomes of the Americas and exhibits a great variety of ecosystems that maintain a high diversity of flora and fauna (Oliveira and Marquis, 2002). This biome has been impacted significantly by human activities during recent decades owing to the rapid expansion of agricultural frontiers in Brazil (Klink and Moreira, 2002; Jepson, 2005). For this reason, the Cerrado is considered a "hot spot" with extreme priority for conservation (Klink and Machado, 2005).

Mauritia flexuosa L. (Arecaceae), commonly known as buriti, is widely distributed in the Cerrado biome and characterizes a typical ecosystem of central Brazil known as vereda. In that phytophysiognomy, M. flexuosa and other groups of arboreal-herbaceous species develop in open fields with very humid soils (Ribeiro and Walter, 1998; Oliveira and Marquis, 2002). M. flexuosa is a palm tree found in forest borders and has a wide distribution in South America (Brazil, Colombia, Venezuela, French Guiana, Ecuador, Peru, and Bolivia). Its height can reach $25 \mathrm{~m}$, its leaves may be as long as 3-4 $\mathrm{m}$, and inflorescences may weigh up to $40 \mathrm{~kg}$ (Henderson et al., 1995). In the Cerrado, M. flexuosa is widely distributed in humid environments of rural areas, periurban environments, and ecological reserves. Several bird and mammal species make their nests in M. flexuosa and use it as a temporary shelter and as a food resource mainly in the dry season when the fruits and seeds are scarce (Prada, 1994).

The population dynamics of plants can significantly affect evolutionary factors such as selection and genetic drift and consequently affect the genetic structure of populations. However, the magnitude of drift and selection on the pattern of genetic variation depends on the reproductive ability of the organism and the rate of gene flow. The relationship between gene dispersal and levels of genetic diversity within populations can be determined by examining the effects of breeding system and pollen dispersal mechanisms on levels of genetic diversity (Hamrick and Nason, 1996). Several methods are available to study the movement of genes within and among populations. One of the most direct methods for studying gene flow is population-specific paternity testing using highly informative microsatellite markers.

Microsatellites, also known as simple sequence repeats, have been increasingly used for genetic studies of tropical forest populations (Collevatti et al., 2001). Such investigations have yielded data that have increased the understanding of population dynamics in a number of species. The main objectives of this study were to develop simple sequence repeat markerenriched libraries and to characterize these loci in buriti palm to facilitate future population studies, such as characterization of the population genetic structure, estimation of crossing rates, and other related parameters important for management and conservation.

\section{MATERIAL AND METHODS}

Total genomic DNA was extracted with $2 \%$ cetyltrimethylammonium bromide 
(Doyle and Doyle, 1987) using a method described by Machado et al. (2002). Microsatellite loci were isolated and identified from a partial genomic library enriched for AG repeats following a protocol described by Rafalski (1996) and modified by Buso et al. (2003). Enriched DNA was ligated into a pGEM-T easy cloning vector (Promega, USA) and transformed into chemically competent Escherichia coli cells. After recovery, the transformed cells were grown overnight on a Luria-Bertani/ampicillin agar plate. Individual positive colonies were picked and regrown for $12 \mathrm{~h}$ on a 96-well culture plate containing $180 \mu \mathrm{L}$ liquid 1X Luria-Bertani/ampicillin solution. Polymerase chain reaction (PCR) amplification of vector inserts using M13 forward and reverse primers was performed directly on the bacterial cultures. The PCR products were purified using ExoSAP (GE Healthcare Life Sciences, USA). The sequencing reactions were performed with the M13 forward primer using Big Dye V3.0 sequencing chemistry (Perkin Elmer, USA) and were visualized on a Perkin Elmer ABI 3700 Genetic Analyzer.

For microsatellite analysis, genomic DNA was extracted from 44 individuals from two natural populations from the Environment Protection Area (Pandeiros) using the same $2 \%$ cetyltrimethylammonium bromide protocol. PCRs were performed on a Gene Amp 9700 (Applied Biosystems, USA) using 5 ng genomic DNA, 1X buffer, $200 \mu \mathrm{M}$ deoxyribonucleotide triphosphates, $1.5 \mathrm{mM} \mathrm{MgCl}, 0.5 \mu \mathrm{M}$ of each primer, and $1 \mathrm{U}$ Taq polymerase (Invitrogen, USA). An initial denaturation step $\left(94^{\circ} \mathrm{C}, 5 \mathrm{~min}\right)$ was followed by 35 cycles of $1 \mathrm{~min}$ at $94^{\circ} \mathrm{C}, 30 \mathrm{~s}$ at the locus-specific annealing temperature (Table 1), $1 \mathrm{~min}$ at $72^{\circ} \mathrm{C}$, and a final extension for $7 \mathrm{~min}$ at $72^{\circ} \mathrm{C}$. PCR products were screened for variability using electrophoresis on $5 \%$ polyacrylamide gels, with visualization by ethidium bromide staining.

Microsatellite locus allele frequency and descriptive locus statistics in the two natural populations of M. flexuosa surveyed were calculated using Genepop (Raymond and Rousset, 1995). The paternity exclusion probability (Weir, 1996) was calculated using the Identity program (Wagner and Sefc, 1999).

\section{RESULTS AND DISCUSSION}

A total of 40 sequences derived from the microsatellite-enriched libraries were selected for primer design. The optimization results showed that 9 primer pairs could successfully amplify polymorphic target fragments of the expected sizes. The number of alleles per locus varied from 12 to 26 with an average of 17.55. The null allele frequency varied from -0.0015 to 0.0864 . The observed and expected heterozygosities ranged from 0 to 0.58 and from 0.88 to 0.96 , respectively (Table 1 ). No pair of loci showed significant linkage disequilibrium. After sequential Bonferroni's correction for multiple tests, all loci were found to depart significantly from Hardy-Weinberg equilibrium. Further tests indicated that heterozygote deficiency at these loci was responsible for the departure (see Table 1). Another possible explanation for the departure from Hardy-Weinberg equilibrium is the dramatic contemporary decline in populations and resulting non-random mating and genetic bottlenecks (Brown et al., 2007; Leclerc et al., 2008). The paternity exclusion power was estimated at 0.8319 for all loci. Our data show that the described primers can be used in population genetic studies to obtain information that will help design conservation and management strategies in M. flexuosa. 
Table 1. Polymorphic microsatellite primer pairs, locus name, repeat motif, primer sequence, size range (bp), specific annealing temperature $(\mathrm{Tm})$, number of alleles $\left(N_{\mathrm{A}}\right)$, observed heterozygosity $\left(H_{\mathrm{O}}\right)$, and expected heterozygosity $\left(H_{\mathrm{E}}\right)$.

\begin{tabular}{|c|c|c|c|c|c|c|c|}
\hline Locus & Repeat motif characterized & Primer sequence $\left(5^{\prime}-3^{\prime}\right)$ & Size range (bp) & $\operatorname{Tm}\left({ }^{\circ} \mathrm{C}\right)$ & $N_{\mathrm{A}}$ & $H_{\mathrm{O}}$ & $\overline{H_{\mathrm{E}}}$ \\
\hline \multirow[t]{2}{*}{$\overline{\mathrm{MF} 3}$} & $(\mathrm{GA})_{10}$ & TCACCGATCTAACTTGACCAAA & & & & & \\
\hline & & TCСТTTCTCTCTCTTGACCCAC & $100-134$ & 56 & 15 & 0 & 0.92 \\
\hline \multirow{2}{*}{ MF8 } & $(\mathrm{AG})_{23}$ & ACCGATCATGGTGGTAGAACTC & & & & & \\
\hline & & AATTCACCGATCAAACCCC & $101-171$ & 56 & 18 & 0.33 & 0.93 \\
\hline \multirow[t]{2}{*}{ MF9 } & $(\mathrm{AG})_{10}$ & ATACATCGCGCATATCTCACTG & & & & & \\
\hline & & ATTCCCACACTCCCTCACTAGA & $113-215$ & 56 & 25 & 0.22 & 0.96 \\
\hline \multirow{2}{*}{ MF11 } & $(\mathrm{AG})_{17}$ & AGAGATTGGGGAGGGGAAG & & & & & \\
\hline & & TCTCCCTCTCTCTTTCGTTGTC & 103-195 & 56 & 21 & 0.13 & 0.95 \\
\hline \multirow[t]{2}{*}{ MF12 } & $(\mathrm{GA})_{7}(\mathrm{GA})_{8}$ & AAACCGAGAGAGAGGGAGAAAG & & & & & \\
\hline & & CTCGTCTGATTTCCTCTTCCTG & $114-178$ & 56 & 26 & 0.46 & 0.94 \\
\hline \multirow{2}{*}{ MF14 } & $(\mathrm{AGA})_{1}$ & CGGGATAGGAGGTTCAGTGTAG & & & & & \\
\hline & & CTCCACCTCTTTGTCTGATTCC & $110-276$ & 56 & 14 & 0.05 & 0.91 \\
\hline \multirow{2}{*}{ MF17 } & $(\mathrm{AG})_{7}(\mathrm{AG})_{8}$ & AGGGCTTCTGGAAGTGTCATAG & & & & & \\
\hline & & TCCTCTTCTTCTCTCCCTCTTG & $155-191$ & 56 & 12 & 0.51 & 0.89 \\
\hline \multirow[t]{2}{*}{ MF18 } & $(\mathrm{CT})_{16}$ & ATCATCGAAGTTTCATCCATCA & & & & & \\
\hline & & CAGAGGGAAATGAACACAGAGA & 154-192 & 48 & 14 & 0.58 & 0.90 \\
\hline \multirow[t]{2}{*}{ MF29 } & $(\mathrm{GA})_{8}(\mathrm{GA})_{9}$ & GATCGGGTGAGGAATTTTGAG & & & & & \\
\hline & & СТCTCTCTCTTCCCTCTCGGAT & $124-196$ & 48 & 13 & 0 & 0.88 \\
\hline
\end{tabular}

\section{ACKNOWLEDGMENTS}

Research supported by Conselho Nacional de Desenvolvimento Científico e Tecnológico (\#555983/2006-4), Fundação de Amparo à Pesquisa do Estado de Minas Gerais and the Unimontes and the State Forest Institute, Minas Gerais.

\section{REFERENCES}

Brown B, Wang HP, Li L, Givens C, et al. (2007). Yellow perch strain evaluation I: genetic variance of six broodstock populations. Aquaculture 271: 142-151.

Buso GSC, Ciampi AY, Moretzohn MC, Amaral ZPS, et al. (2003). Marcadores microssatélites em espécies vegetais. Biotecnol. Cienc. Desenvol. 30: 46-50.

Collevatti RG, Grattapaglia D and Hay JD (2001). High resolution microsatellite based analysis of the mating system allows the detection of significant biparental inbreeding in Caryocar brasiliense, an endangered tropical tree species. Heredity 86: 60-67.

Doyle JJ and Doyle JL (1987). Isolation of plant DNA from fresh tissue. Focus 12: 13-15.

Hamrick JL and Nason JD (1996). Consequences of Dispersal in Plants. In: Population Dynamics in Ecological Spaceand Time (Rodhes OEJ, Chesser RK and Smith MH, eds.). University of Chicago Press, Chicago, 203-236.

Henderson A, Galeano G and Bernal R (1995). Field Guide to the Palms of the Americas. Princeton University Press, Princeton. Jepson W (2005). A disappearing biome? Reconsidering land-cover change in the Brazilian savanna. Geograph. J. 171: 99-111.

Klink CA and Moreira AG (2002). Past and Current Human Occupation and Land Use. In: The Cerrados of Brazil: Ecology and Natural History of a Neotropical Savanna (Oliveira PS and Marquis RJ, eds.). Columbia University Press, New York, 69-88.

Klink CA and Machado RB (2005). Conservation of the Brazilian Cerrado. Conserv. Biol. 19: 707-713.

Leclerc E, Mailhot Y, Mingelbier M and Bernatchez L (2008). The landscape genetics of yellow perch (Perca flavescens) in a large fluvial ecosystem. Mol. Ecol. 17: 1702-1717.

Machado FRB, Vinson CC, Silva VP and Ciampi AY (2002). Extração de DNA Genômico de Câmbios de Espécies Madeireiras Tropicais. $53^{\circ}$ Congresso Nacional de Botânica, Pernanbuco, Brasil. Sociedade Brasileira de Botânica, Recife.

Oliveira PS and Marquis RJ (2002). The Cerrados of Brazil: Ecology and Natural History of a Neotropical Savanna. Columbia University Press, New York.

Prada MV (1994). Guilda de Frugívoros Associada com o Buriti (Mauritia Flexuosa: Palmae) numa "Vereda" no Brasil 
Central. Master's thesis, Universidade de Brasília, Brasília.

Rafalski DJA (1996). Generating and Using DNA Markers in Plant. In: Non-Mammalian Genomic Analysis: A Practical Guide (Birren B and Lai E, eds.). Academic, New York, 75-134.

Raymond M and Rousset F (1995). GENEPOP version 1.2: population genetics software for exat tests and ecumenicism. J. Heredity 248-249.

Ribeiro JF and Walter BMT (1998). Fitofisionomias do Bioma Cerrado. Cerrado Ambiente e Flora, In: Cerrado Ambiente e Flora (Sano SM and Almeida SP, eds.). Embrapa, Planaltina, 89-166.

Wagner HW and Sefc KM (1999). IDENTITY 1.0 Center for Applied Genetics, University of Agricultural Sciences, Vienna.

Weir BS (1996). Genetic Data Analysis II: Methods for Discrete Population Genetic Data. Sinauer Assoc. Inc., Sunderland. 